\title{
RELIGIJNO-PATRIOTYCZNE OBCHODY 70. ROCZNICY ODZYSKANIA PRZEZ POLSKĘ NIEPODLEGLOŚCI W KATEDRZE NA WAWELU (11 XI 1988 R.) W RELACJI ZDZISŁAWA CHŁOPKA
}

Już od początku dwudziestolecia międzywojennego, każdego roku, obchodzono święto 11 listopada jako rocznicę odzyskania przez Polskę niepodległości, aczkolwiek oficjalnie 11 listopada jako Święto Niepodległości ustanowiono dopiero w roku 1937. W ustawie z 23 kwietnia 1937 r. czytamy: „dzień 11 listopada, jako rocznica odzyskania przez Naród Polski niepodległego bytu państwowego i jako dzień po wsze czasy związany z wielkim imieniem Józefa Piłsudskiego, zwycięskiego Wodza naczelnego w walkach o wolność Ojczyzny - jest uroczystym Świętem Niepodległości”. Ustawa wyraźnie związała święto z osobą I Marszałka.

\section{Obchody Święta Niepodległości w latach poprzedzających wybuch II wojny światowej}

Najbliższy po ustanowieniu święta, dzień 11 listopada 1937 r. był już obchodzony jako Narodowe Święto Niepodległości. Stał się dniem odprawiania nabożeństw w intencji Ojczyzny, organizowania akademii, wieczornic oraz parad wojskowych. Litera i duch ustawy zapowiadały, że miejscem szczególnym obchodu święta 11 listopada będzie katedra na Wawelu, a w niej krypta marszałka Józefa Piłsudskiego, do której przeniesiono trumnę Marszałka w czerwcu tego roku. Podejmujemy więc próbę odpowiedzi na pytanie jak świętowano dzień 11 listopada w katedrze na Wawelu przez kolejne lata, zwłaszcza w kolejne dziesięciolecia, by się zatrzymać nad rokiem 1988, rokiem 70-lecia odzyskania niepodległości, który miał się okazać zupełnie szczególnym.

11 listopada 1937 r. biskup pomocniczy Archidiecezji Krakowskiej Stanisław Rospond, w katedrze wawelskiej odprawił Mszę św. w intencji Ojczyzny. Po jej zakończeniu uczestnicy liturgii zeszli do krypty Marszałka J. Piłsudskiego, w której odmówiono modlitwy. W roku następnym 11 listopada 1938 r. święto Niepodległości znowu obchodzono uroczyście. Tytułem do szczególnego dziękczynienia było 20-lecie odzyskania niepodległości. Na Mszy św. w intencji Ojczyzny obecni byli m.in. przedstawiciele władzy - wojewoda krakowski Józef Tymiński i generał Bernard Mond¹.

1 I. Fischer, Obchody Święta Niepodległości w międzywojennym Krakowie, „Sowiniec” 15 (1999), s. 42-47; P. Kajzar, Mauzoleum marszałka Józefa Piłsudskiego na Wawelu w latach 1935-1989, Kraków 2019, s. 244. 
Uroczystość 11 listopada 1939 r. już się nie odbyła. Kilka dni wcześniej władze okupacyjne niemieckie zażądały kluczy do katedry. Wzgórze Wawelskie stało się zoną wojskową. Wszyscy duchowni i świeccy mieszkańcy Wawelu musieli opuścić Wzgórze. Na długich pięć lat okupacji katedrę zamknięto².

W latach II wojny światowej pamięć o Święcie Niepodległości przechowywano jedynie w Polskich Siłach Zbrojnych na Zachodzie oraz w instytucjach państwa polskiego na wychodźstwie ${ }^{3}$.

\section{1 listopada w katedrze na Wawelu w okresie PRL-u}

Po zakończeniu II wojny światowej, nowe komunistyczne władze zniosły ustawą Krajowej Rady Narodowej z 22 lipca 1945 r. Narodowe Święto Niepodległości, wprowadzając nowe święto pod nazwą Narodowe Święto Odrodzenia Polski, obchodzone odtąd 22 lipca. Równocześnie komunistyczne władze nie pozwoliły na otwarcie i udostępnienie krypty J. Piłsudskiego w katedrze na Wawelu. Wejście do krypty zabito deskami. Świadectwem pamięci o J. Piłsudskim były kwiaty składane u progu krypty. Niektórzy przechodzący na wysokości krypty J. Piłsudskiego czynili znak Krzyża św. W takim stanie krypta pozostawała zamknięta aż do „politycznej odwilży" roku 1956. Dopiero wtedy komunistyczne władze wyraziły zgodę na otwarcie krypty. Kryptę należało doprowadzić do porządku po jej kilkunastoletnim zamknięciu (licząc lata okupacji i zimnej wojny) 4

Krypta znów stała się miejscem spotkań legionistów. Wszystkie terminy spotkań były związane z J. Piłsudskim. Było ich kilka w ciągu roku. To, przyjmując chronologię w ciągu roku: dzień imienin Marszałka (19 marca), dzień jego śmierci (12 maja), dzień wymarszu I Kadrowej (6 sierpnia), zniesione przez władze święto Niepodległości (11 listopada) i dzień urodzin Marszałka (5 grudnia)5.

Miejscem sprawowania Mszy św. w intencji Ojczyzny najczęściej był ołtarz Krzyża św. Jadwigi Królowej, a celebransem był wówczas ks. kanonik Kazimierz Figlewicz, proboszcz katedry na Wawelu. W modlitwie uczestniczyli przede wszystkim legioniści wraz ze swoim pocztem sztandarowym. Pamiętano, że kilka razy uczestniczył w niej Eugeniusz Kwiatkowski. Po Mszy św. do krypty schodzili przede

2 J. Urban, Katedra na Wawelu $w$ relacji ks. Kazimierza Figlewicza $w$ latach 1939-1945, „Analecta Cracoviensia” 28 (1996), s. 569-580.

3 Wprawdzie 11 listopada 1944 r. na ziemiach już wyzwolonych obchodzono Święto Niepodległości w Lublinie, gdzie ulokowały się Krajowa Rada Narodowa i Polski Komitet Wyzwolenia Narodowego, ale była to uroczystość obliczona przede wszystkim na przypodobanie się społeczeństwu.

4 Na kartach w/w książki P. Kajzara wszystkie te osoby i ich zasługi zostały szczegółowo omówione.

5 Ks. M. Jagosz dla lat 1963-1978 wymienia przede wszystkim trzy: 19 marca, 6 sierpnia i 11 listopada. Zob. M. Jagosz, Katedra wawelska za czasów pasterzowania arcybiskupa Karola Wojtyły, w: Karol Wojtyła jako biskup krakowski, red. T. Pieronek, R. Zawadzki, Kraków 1988, s. 139. Ich rozszerzenie do pięciu należy już do okresu po roku 1978. 
wszystkim legioniści ${ }^{6}$. Po tym jak wszyscy zajęli miejsca, rozpoczynano ceremonię. Najpierw wygłaszano rocznicową inwokację w rodzaju: „zebraliśmy się tutaj aby świętować x rocznicę...". Prowadzącymi ceremonię byli legioniści. Po wstępie, ks. K. Figlewicz (najczęściej on) odmawiał modlitwę. Była to modlitwa za marszałka J. Piłsudskiego i za jego żołnierzy. Po modlitwie wygłaszano przemówienie. W latach 1956-1974 przemówienia te wygłaszał dr Stanisław Korczyński, komendant naczelny Związku Legionistów Polskich, który to związek działał w konspiracji jako „Grupa Oleandry”. Dr S. Korczyński wypełniał to zaszczytne zadanie aż do końca życia w roku 19747 . Po przemówieniu następowało złożenie kwiatów, a na zakończenie śpiew „Pierwszej brygady”. O ile Msza św. przy Krzyżu św. królowej Jadwigi była odprawiana w intencji Ojczyzny, o tyle modlitwy w krypcie i przemówienia odnoszone były do marszałka J. Piłsudskiego i jego żołnierzy. Obchodzenie 11 listopada zapewne miało podobną formę jak i pozostałych w/w rocznic.

Zniesione przez władze Narodowe Święto Niepodległości można było obchodzić jedynie w kościołach. Zarówno ludzie przybyli na to nabożeństwo, jak i homilie wtedy wygłaszane, poddane były inwigilacji ze strony Służby Bezpieczeństwa. Władze konsekwentnie marginalizowały znaczenie 11 listopada. Wyjątek potwierdzający regułę to 11 listopada 1968 r., kiedy to obchodzono 50 lat odzyskania przez Polskę niepodległości ${ }^{8}$.

11 listopada 1968 to był poniedziałek. Wobec tego uroczystość przybrała charakter dwudniowy. Najpierw odprawiono je w niedzielę 10 listopada. Oddajmy głos ks. K. Figlewiczowi proboszczowi katedry na Wawelu i autorowi Kroniki katedralnej: „Obchodzono 50-lecie odzyskania wolności w roku 1918. O godz. 9.45 dzwonił „Zygmunt”; było powitanie ks. kardynała K. Wojtyły, który brał udział we Mszy św. odprawionej przez Hebdomadariusa (x. Figlewicz); zamiast kazania czytano list Episkopatu, po Sumie było wystawienie Najświętszego Sakramentu i X. Kardynał po odśpiewaniu Suplikacji, odmówił modlitwy, ułożone w tym celu przez X. Kardynała Prymasa i po „Te Deum” udzielił błogosławieństwa eucharystycznego; na zakończenie odśpiewano „Boże coś Polskę”. Natomiast 11 listopada o godz. 18, X.

${ }^{6}$ Jak wspomina Krystian Waksmundzki tylko legioniści mieli prawo wejść do krypty w maciejówkach. Z czasem legioniści zgodzili się, żeby w maciejówkach występował także poczet sztandarowy wystawiany przez Związek Legionistów Polskich. Zob. P. Kajzar, Mauzoleum..., dz. cyt., s. 304-309.

7 P. Kajzar, Mauzoleum..., dz. cyt., s. 304.

8 Komunikato nabożeństwie w katedrze na Wawelu w 50. rocznicęodzyskania niepodległości, w: Nauczyciel i Pasterz. Kardynat Karol Wojtyła, red. M. Jagosz, Rzym 1987, s. 253. W niedzielę 10 listopada z ambon Archidiecezji krakowskiej, prócz krakowskiej odczytano komunikat ks. kard. K. Wojtyły następującej treści: „W związku z 50-leciem odzyskania przez Naród Polski w 1918 roku niepodległości, odprawię w Katedrze na Wawelu Mszę św. za tych wszystkich naszych Rodaków, którzy swym życie i śmiercią przysłużyli się tej wielkiej sprawie. Msza św. zostanie odprawiona w dniu jutrzejszym, 11 listopada, o godzinie 18, na którą wiernych miasta Krakowa serdecznie zapraszam”. 
Kardynał odprawił żałobną Mszę św. pontyfikalną za dusze Rodaków, którzy życiem lub śmiercią ofiarną przyczynili się do odzyskania tejże wolności; po Mszy św. X. Kardynał przemówił, a następnie odmówił modlitwy za w/w Rodaków przy grobie kardynała Sapiehy; wreszcie odśpiewano „Salve Regina” i „Anioł Pański”. Udział wiernych był znaczny, zwłaszcza sióstr zakonnych i starszego pokolenia".

Po zakończeniu uroczystości w katedrze uczestnicy zeszli do krypty Marszałka. Dla wielu zaskoczeniem była nowa płyta w krypcie z orłem z koroną w górnej części, z płaskorzeźbą Józefa Piłsudskiego, napisem „11 XI 1918 - 11 XI 1968” i z krzyżami Niepodległości w narożnikach, którą potajemnie zainstalowano w przeddzień uroczystości. Jej wykonawcą był dawny legionista i AK-owiec Wacław Szacoń. Prawdopodobnie było to, po II wojnie światowej, pierwsze miejsce w Polsce, w którym podobizna marszałka J. Piłsudskiego została wystawiona na widok publiczny ${ }^{10}$.

Były to lata, w których ważnym wsparciem dla legionistów stał się metropolita krakowski kard. Karol Wojtyła. Pamiętano mu m.in. wystąpienie na opłatku legionowym w Krakowie w klasztorze dominikanów, 25 stycznia 1975 r., na którym powiedział: „Dobrze, że się tu spotykacie, dobrze, że strzeżecie tych wszystkich śladów i tej rocznicy 6-sierpnia i tej drogiej sercu Polaka trumny Marszałka i tego postumentu na dawnej granicy pod Michałowicami, którą niegdyś przekraczały pierwsze oddziały wojska polskiego, zdecydowane by walczyć o niepodległość. Dobrze, że tego wszystkiego strzeżecie, pilnujecie, bo to są skarby narodu, to jest nasze wspólne dziedzictwo, należą do Wawelu, należą do skarbca pamiątek narodu, tak jak wszystko co się w Krakowie, a zwłaszcza w tym królewskim Wawelu znajduje"11.

Tymczasem z każdym kolejnym rokiem topniały szeregi legionistów. Ich pogrzeby często prowadził ks. K. Figlewicz pełniący obowiązki kapelana legionistów. Pozostali przy życiu przyjmowali w szeregi nieformalnie istniejącego Związku Legionistów Polskich, ludzi wychowanych w tradycjach niepodległościowych, sprawdzonych, stale obecnych przy kolejnych rocznicach i uczestniczących w pracach Związku. W 1975 r. został nim m.in. Krystian Waksmundzki. To jemu po śmierci dr Korczyńskiego, przypadało w udziale wygłaszać przemówienia w krypcie marszałka J. Piłsudskiego. Ustępował tego wyróżnienia, gdy wolę przemawiania wyrażali: generał Mieczysław Boruta-Spiechowicz, pułkownik Henryk Bezeg, major Józef Herzog, kapitan Kazimierz Martyniak, porucznicy Stanisław Leszczyc-Przywara i Jan Łobodziński, czy Jan Dębosz. Przypomnijmy fragment przemówienia gen. M. Boruty-Spiechowicza z 11 listopada 1977 r.

„Zawierucha ostatnia, która przeszła nad światem, nie minęła jeszcze, a pioruny nieprawości rażą i ranią serce Narodu i ducha starej wiary śmiertelnie, ale pamię-

9 K. Figlewicz, Kronika katedry na Wawelu 1934-1982, opr. J. Urban, E. Zych, Kraków 2014, s. 365.

10 P. Kajzar, Mauzoleum..., dz. cyt., s. 168-169.

11 Przemówienie J.E. kardynała Karola Wojtyły na opłatku legionowym w Krakowie w dniu 25 I 1975 r., ,Sowiniec” 6 (1986), s. 41. 
tajcie i tę świadomość nieście w sobie do końca, że kto walczy o ogólne wartości i o powszechną sprawiedliwość, ten przyczynia się do obrony Narodu - wszystkich ludzi na świecie - od upodlenia. Nie z bałwochwalstwa zrodziła się nasza wiara, a z umiłowania celów jakie nam wskazałeś. Byłeś dla nas urzekającym wzorem i takim pozostaniesz dla pokoleń, które nadchodzą! Śpij spokojnie, Panie Marszałku!. Stara wiara wierna do końca... nie zawiedzie"12.

Dzień 11 listopada 1978 r. oznaczał 60-lecie święta. Tymczasem władze jak co roku przygotowywały się do kolejnej rocznicy rewolucji październikowej. W trakcie ich przygotowania doszło do wyboru kard. Karola Wojtyłę na papieża. To właśnie wtedy Ruch Obrony Praw Człowieka i Obywatela otrzymał silne wsparcie ze strony środowisk kombatanckich, niepodległościowych, studenckich, a także Kościoła katolickiego. Uroczystości odbyły się w Gdańsku, Krakowie, Lublinie, Łodzi i Warszawie. Wtedy też po raz pierwszy od zakończenia II wojny światowej kościelne obchody przemieniły się w manifestacje patriotyczne na ulicach wielkich polskich miast. W Krakowie w siłę rosła opozycja odwołująca się do tradycji piłsudczykowskich. Określała ją w dużym stopniu Konfederacja Polski Niepodległej. 9 listopada 1978 r. krypta J. Piłsudskiego w katedrze na Wawelu została udekorowana dwoma flagami biało-czerwonymi, datami 1918-1978, orłem w koronie i emblematem Polski Walczącej. W sam dzień 11 listopada w godzinach przedpołudniowych katedrę wypełnili przede wszystkim młodzi ludzie, co warte podkreślenia. Przybyli także gen. M. Boruta-Spiechowicz i konsul Stanów Zjednoczonych Ameryki Północnej. O godz. 9-ej ks. prałat K. Figlewicz odprawił Mszę św., po której przez dwie i pół godziny ludzie podchodzili do trumny Marszałka w jego krypcie, by oddać hołd jego cieniom. W południe ks. Franciszek Walancik, proboszcz katedry na Wawelu po ks. K. Figlewiczu, polecił rozkołysać dzwon z fundacji króla Zygmunta ${ }^{13}$.

Rok następny przyniósł pierwszą pielgrzymkę apostolską papieża Jana Pawła II do Ojczyzny w czerwcu 1979 r. Wywołała ona ogromny entuzjazm. Dała poczucie siły i jedności. 11 listopada 1979 r. znowu, przede wszystkim ludzie młodzi, przybyli do katedry. Po Mszy św. w katedrze i złożeniu hołdu w krypcie J. Piłsudskiego część ludzi młodych przybyłych na Mszę św. zorganizowała przejście z Wawelu drogą

12 Archiwum Kapitulne na Wawelu [dalej: AKKK], b. sygn., Spuścizna M. Boruty-Spiechowicza, Przemówienie M. Spiechowicza u grobu J. Piłsudskiego, 11 XI 1977 r.

${ }^{13}$ Ks. K. Figlewicz w swojej kronice pod datą 11 XI 1978 r. pisał: „o godz. 9 była odprawiona Msza św. za duszę śp. Marszałka Józefa Piłsudskiego z okazji 60-lecia odzyskania niepodległości Polski w roku 1918; przyszło bardzo wiele ludzi, którzy zapełnili bazylikę i stali aż na stopniach wielkiej bramy; obecny był na Mszy św. gen. Boruta-Spiechowicz, 3 kapłanów rozdzielało Komunię św.; po Mszy św. zebrani wierni schodzili do Grobów Królewskich i oddawali hołd Marszałkowi”. Zob. K. Figlewicz, Kronika katedry..., dz. cyt., s. 489, Instytut Pamięci Narodowej Oddział w Krakowie [dalej: IPN Kr], sygn. IPN Kr 010/9303/4, Informacja operacyjna [na temat nabożeństwa w katedrze 11 XI 1978]; W. Ziembiński, 11 listopada 1978, „Opinia. Pismo ROPCiO”, październik-listopad 1978, s. 12-15. 
królewską na plac Matejki, przed Grób Nieznanego Żołnierza. Nieśli flagi i proporce. Jeden z przedstawieniem orła w koronie, a drugi z napisem „Konfederacja Polski Niepodległej”. Po przybyciu na miejsce odśpiewali hymn „Jeszcze Polska nie zginęła". Chwilę później zostali zaatakowani przez Milicję Obywatelską. Kilkanaście osób zostało zatrzymanych. Zostali oni ukarani przez Kolegium ds. Wykroczeń wysoką grzywną. Interwencja MO była w dotychczasowych dziejach obchodu 11 listopada zjawiskiem nowym ${ }^{14}$.

Tak nadszedł rok 1980, rok „Solidarności”. Od czerwca 1980 r. odpowiedzialność za organizację uroczystości w krypcie przejął Obywatelski Komitet Opieki nad Kopcem Józefa Piłsudskiego działający przy Towarzystwie Miłośników Historii i Zabytków Krakowa, w imieniu Związku Legionistów Polskich. We Mszy św. 11 listopada 1980 r. uczestniczyły już tłumy. W katedrze na Wawelu pojawiły się poczty sztandarowe „Solidarności” z różnych zakładów pracy, a zwłaszcza „Solidarność" Nowej Huty, a także młodzież szkolna, wśród niej młodzież z Gimnazjum Nowodworskiego. Mszy św. przewodniczył metropolita krakowski kard. Franciszek Macharski. Ogłoszono, że Msza św. odprawiana jest za Ojczyznę. Po Mszy św. grono legionistów poszerzyło się o działaczy „Solidarności”. Do krypty schodzili m.in. działacze NSZZ Solidarność: Mieczysław Gil, Stanisław Handzlik, Edward Nowak i sekretarz zarządu Regionu Solidarności Stanisław Kuś ${ }^{15}$. Obok pocztu sztandarowego legionistów, poczet sztandarowy AK, konsulowie Stanów Zjednoczonych i Francji, delegacje $\mathrm{z}$ wieńcami i wiązankami kwiatów ${ }^{16}$.

Po zaprowadzeniu stanu wojennego katedra na Wawelu w dniu 11 listopada była miejscem, na które przychodziły tłumy ludzi liczone w tysiące. Organizatorzy dokładali starań, by ceremonie w krypcie marszałka J. Piłsudskiego nie zostały wykorzystane przez władze. Zdawano sobie sprawę, że wśród przybyłych do katedry byli także funkcjonariusze Urzędu Bezpieczeństwa. Obawiano się prowokacji. W przemówieniach wygłaszanych w krypcie podkreślano, że celem jest oddanie hołdu Marszałkowi i jego żołnierzom. Proszono i przestrzegano, by krypta nie stała się miejscem wykorzystanym dla polityki. Te apele były kierowane m.in. do najbardziej radykalnych członków Konfederacji Polski Niepodległej.

Od 11 listopada 1982 do 11 listopada 1987 r. scenariusz uroczystości był podobny. Najpierw o godzinie 17-ej miał miejsce hołd dla Marszałka w jego krypcie z udziałem ostatnich legionistów, delegacji z całej Polski i osób zaproszonych. Obecni byli legioniści, przedstawiciele córek Marszałka, przedstawiciele organizacji niepodległościowych, Bractwo Kurkowe, przedstawiciele harcerzy, przedstawiciele zdelegalizowanej „Solidarności”, konsulowie Stanów Zjednoczonych Ameryki Pół-

14 Opozycja Małopolska w dokumentach 1976-1980, Kraków 2003, s. 963-964; Dokumenty uczestników Ruchu Obrony Praw Człowieka i Obywatela 1977-1981, Kraków 2005, s. 307-309.

15 Encyklopedia Solidarności. Opozycja w PRL 1976-1989, t. 1., Warszawa 2010, s. 124 125; Encyklopedia Solidarności..., dz. cyt., s. 146.

16 IPN Kr, sygn. IPN Kr 010/9303/4, Meldunek operacyjny z 11 XI 1980 r. 
nocnej i Francji ${ }^{17}$. Legioniści zaciągali wartę. Modlitwy prowadził ks. prałat Janusz Bielański, proboszcz katedry na Wawelu. W imieniu Komitetu przemawiał Krystian Waksmundzki, w imieniu Konfederacji Polski Niepodległej Leszek Moczulski, przemawiali także przedstawiciele społeczności związkowej Małopolski, m.in. Mieczysław Gil i Edward Nowak. Następnie o godz. 18-ej Msza św. w katedrze na Wawelu z kazaniem. Katedra każdego roku była przepełniona. Wielu musiało pozostać na dziedzińcu przed katedrą. Po Mszy św. zejście delegacji do krypty marszałka J. Piłsudskiego. Pożegnanie śpiewem „Pierwszej Brygady”. W tym czasie na zewnątrz katedry, na dziedzińcu, formowano demonstrację. Ze skandowanymi hasłami takimi jak: „Solidarność”, „Lech Wałęsa”, „Zbyszek Bujak”, schodzili z Wawelu. Pod Wawelem demonstranci byli każdego roku brutalnie rozpędzani przez ZOMO i MO, a najdzielniejsi aresztowani i skazywani na grzywny ${ }^{18}$.

W tym smutnym okresie naszych dziejów odchodzili ostatni już legioniści ${ }^{19}$. Rok 1985 był rokiem 50-lecia śmierci Józefa Piłsudskiego. W tym roku kolejno odchodzili jego żołnierze: generał Tadeusz Pełczyński (+3 I 1985), porucznik Stanisław Przywara (+5 I 1985), generał Tadeusz Alf-Tarczyński (+26 I 1985), generał Mieczysław Boruta-Spiechowicz (+13 X 1985), kapitan Kazimierz Martyniak, prezes Związku Legionistów Polskich w Krakowie $\left(+27\right.$ X 1985) ${ }^{20}$. Po śmierci ks. K. Figlewicza, który był nieformalnym kapelanem legionistów nowym proboszczem katedry został ks. prałat Janusz Bielański, który jako gospodarz czuwał nad przebiegiem uroczystości w katedrze, natomiast miejsce ks. K. Figlewicza jako kaznodziei i tego, który odprowadza trumny kolejnych legionistów zajął ks. prałat Stanisław Małysiak, kanonik Kapituły Katedralnej na Wawelu, a w latach II wojny światowej członek Armii Krajowej. Do Mszy św. celebrans najczęściej używał ornatu z wizerunkiem Virtuti Militari.

W latach osiemdziesiątych XX w. odchodzili ostatni legioniści, ale też właśnie wtedy, liczniej niż w poprzednich latach, pojawili się harcerze. Krakowską młodzieżą harcerską zajął się dr Jerzy Bukowski. On też zajął się z młodzieżą w Komitecie Opieki nad Kopcem J. Piłsudskiego przy Towarzystwie Miłośników Historii i Zabytków Krakowa. To wtedy już wyraźnie w środowisku post-legionowym, ujawnił się widoczny podział w uroczystościach organizowanych w krypcie marszałka J. Piłsudskiego ${ }^{21}$.

${ }_{17}$ M.in. w 1985 r. obecny był konsul Stanów Zjednoczonych Charles Smith Jr.

18 Kalendarium roku Marszałka Józefa Pitsudskiego w Krakowie, opr. J. Giza, B. Kuras, W. Steckiewicz, „Sowiniec”. Materiały historyczne i dokumenty, Kraków 1985, s. 6; J. Urban, Katedra na Wawelu po 1918 r., Kraków 2008, s. 362; M. Lewandowski, M. Pawlikowski, Gaz na ulicach, Kraków 2011, t. 1, s. 577 (11 XI 1982 r.).

19 Major Józef Herzog (1901-1983) zmarł 21 stycznia 1983 r., a 23 września 1983 r. zmarł kapelan legionistów ks. infułat Kazimierz Figlewicz (1903-1983).

20 Legionista 6 pp III Brygady Legionów Polskich. Zob. J. Nowak, Pamięci Pana Kazimierza Martyniaka, „Sowiniec” 5 (1985), s. 33.

${ }^{21}$ Podział widać w Kronice katedry na Wawelu z 11 XI 1988 r. Oto o godz. 11-ej legioniści 
Tak nadszedł rok 1988, który okazał się niezwykłym. W przeddzień 11 listopada kronikarz katedry na Wawelu zapisał: W południe, w obecności kompanii reprezentacyjnej „czerwonych beretów” i orkiestry tychże, przybyła delegacja rządu PRL z K. Barcikowskim - któremu towarzyszył J. Gozdowski - która złożyła wiązanki kwiatów na trumnie J. Piłsudskiego i sarkofagu dla W. Sikorskiego. Orkiestra odegrała hymn państwowy i marsz I Brygady. Była to chyba pierwsza w powojennej Polsce delegacja rządowa, która oficjalnie oddała hołd Naczelnikowi Państwa”"22.

Kazimierz Barcikowski w latach 1977-1980 był I sekretarzem KK PZPR w Krakowie. W 1980 r. wraz z kard. F. Macharskim był wiceprzewodniczącym Komisji Wspólnej Rządu i Episkopatu, a od 1985 r. wiceprzewodniczącym Rady Państwa. Obecność tego polityka przy trumnie marszałka J. Piłsudskiego 10 listopada $1988 \mathrm{r}$. zapowiadała zmianę kursu ${ }^{23}$.

To co się zdarzyło w krypcie J. Piłsudskiego 10 listopada 1988 r. wymaga cofnięcia się do roku 1985, do dojścia do władzy Michaiła Gorbaczowa w ZSSR i podjęcia przez niego próby reformy państwa sowieckiego określanej jako „pierestrojka”. Radziecka „pierestrojka”, dała asumpt do jeszcze większej aktywności opozycji w państwach sowieckiego bloku, w tym szczególnie w Polsce. Jest to także moment spotkania historii politycznej z historią Kościoła. W październiku 1986 r. Michaił Gorbaczow został przyjęty na Watykanie przez papieża Jana Pawła II. Niedługo potem został przyjęty Wojciech Jaruzelski, który zaprosił Jana Pawła II do Polski. Odtąd podjęto wspólne przygotowania do III pielgrzymki Papieża Polaka do Ojczyzny. Na posiedzeniach Komisji Wspólnej postanowiono o intensyfikacji prac nad statusem prawnym Kościoła katolickiego w Polsce oraz doprowadzeniem do końca sprawy przywrócenia stosunków dyplomatycznych z Watykanem. Pielgrzymka Jana Pawła II w czerwcu 1987 r. nie zakończyła się sukcesem władz. Gen. Czesław Kiszczak do członków Biura Politycznego 19 czerwca 1987 r. mówił, iż należy się spodziewać uaktywnienia kierowniczych gremiów opozycji, która została dowartościowana przez papieża. Zdaniem Kiszczaka opozycja będzie szukać protekcji Kościoła, dalej będzie dążyć do usankcjonowania pluralizmu politycznego i związkowego, zwiększając nacisk na uznanie prawa do związków zawodowych. Ponadto opozycja

osobno przybyli do krypty J. Piłsudskiego, po południu osobno harcerze, a o godz. 17ej osobno „Solidarność” i opozycja. Zob. Archiwum Kapituły Katedralnej w Krakowie [dalej: AKKK], b. sygn. Kronika katedry na Wawelu (1986-1997), k. 6.

22 AKKK, b. sygn. Kronika katedry na Wawelu (1986-1997), k. 6. Autorem relacji był piszący te słowa, podówczas podkustoszy katedry na Wawelu. Żołnierze 6 Pomorskiej Brygady Powietrzno-Desantowej zaciągnęli wartę honorową w krypcie marszałka J. Piłsudskiego. Harcerze utworzyli szpaler, pośród którego do Grobów Królewskich przeszły delegacje władz. Delegacja rządowa to: zastępca przewodniczącego Rady Państwa Kazimierz Barcikowski, wicemarszałek Sejmu Jerzy Ozdowski i minister szef Kancelarii Rady Państwa Jerzy Brelkopf. Władze wojskowe reprezentowali gen. Jerzy Skalski i gen. Józef Kuropieska, a władze Miasta Krakowa, prezydent Tadeusz Salwa, Józef Gajewicz i Apolinary Kozub.

${ }^{23}$ K. Barcikowski, jak mówił, od młodych lat był pod dużym wrażeniem J. Piłsudskiego. 
będzie dążyć do „dalszych ustępstw w zakresie liberalizacji wewnętrznej, szczególnie w sferze tak zwanych praw człowieka, poprzez dyskredytowanie polityki porozumienia". Władze komunistyczne w obawie o sojusz Kościoła z opozycją postanowiły go uniemożliwić podejmując decyzję o „odmrożeniu” relacji z Kościołem. Jednym ze zwolenników tego kierunku był Kazimierz Barcikowski, który stojącym na dotychczasowych antykościelnych pozycjach przypominał, że ,jedne z pierwszych przejawów pierestrojki miały miejsce właśnie na odcinku wyznaniowym"24. W kręgach komunistycznych władz, przewagę zyskała koncepcja użycia Kościoła jako gwaranta „porozumienia narodowego”. W tym kierunku poszła decyzja podjęta w październiku 1987 r. na posiedzeniu Biura Politycznego. Powołano wtedy zespół do koordynacji przygotowań do uregulowania statusu Kościoła w Polsce. Na jego czele stanął Kazimierz Barcikowski, a członkami zostali Czesław Kiszczak i Stanisław Ciosek ${ }^{25}$.

Pogarszająca się koniunktura, skłoniła władze na początku 1988 r. do ogłoszenia podwyżki artykułów żywnościowych (o ponad 25\%), przemysłowych (o ok. $30 \%$ ) i usług (o 40\%). Najbardziej ucierpiała tzw. strefa budżetowa. Odpowiedzią była fala strajków najpierw w maju, a następnie w sierpniu. Obok postulatów ekonomicznych nieodmiennie obecne było żądanie legalizacji „Solidarności”. W ciągu 1988 r. ceny wzrosły o ok. $60 \%$, a inflacja o $80 \%$. Nadal obowiązywał centralny system reglamentacji.

Władze próbowały pozyskać Kościół, z jednej strony prowadząc rozmowy w Komisji Wspólnej o wypracowanie podstawy do trwałego uregulowania stosunków między państwem a Kościołem, a z drugiej sugerując by Episkopat rozważył możliwość powołania kościelnych organizacji społeczno-politycznych. Ponadto władze zachęcały do zaprowadzenia zmian w PRON-ie, by „stał się płaszczyzną porozumienia", ale władze kościelne nie dały się sprowokować ${ }^{26}$. We wrześniu 1988 r. premiera Zbigniewa Messnera zastąpił Mieczysław Rakowski. Nowe władze zdecydowały się podjąć współpracę z umiarkowaną częścią opozycji. Do

${ }^{24}$ K. Barcikowski, U szczytów władzy, Warszawa 1998, s. 436.

25 A. Dudek, R. Gryz, Komuniści i Kościót w Polsce (1945-1989), Kraków 2000, s. 432.

${ }^{26}$ W komunikacie z 227 Konferencji Plenarnej Episkopatu Polski z 2-3 V 1988 r. czytamy: „Obywateli mających poczucie odpowiedzialności za losy kraju muszą napawać lękiem ostatnie niepokoje i strajki w niektórych ośrodkach przemysłowych. Biskupi mogą zrozumieć motywy i determinację robotników, którzy podjęli akcję protestacyjną. Starają się również rozeznać przyczyny, które do niej doprowadziły. Bolesne doświadczenia ostatnich lat, a także troska o losy narodu, powinny skłonić do wspólnego poszukiwania nowych dróg prowadzących do spotkania i współdziałania władzy i społeczeństwa. Biskupi przypominają, że zgodnie ze społeczną nauką Kościoła, społeczeństwo ma prawo dochodzić własnej podmiotowości (...). Jedynym środkiem prowadzącym do przezwyciężenia kryzysu kraju jest dialog władz państwowych i reprezentatywnych grup społecznych. Według powszechnej opinii żaden rząd ani żaden obóz polityczny nie zdołają rozwiązać palących problemów naszego kraju bez szerokiego udziału społeczeństwa. Zob. Komunikaty Konferencji Episkopatu Polski 1945-2000, opr. J. Żaryn, Warszawa 2006, s. 333. 
rozmów potrzebowały Kościoła. W Warszawie 31 sierpnia 1988 r. doszło do spotkania Czesława Kiszczaka z Lechem Wałęsą. Przyjmuje się, że było to spotkanie, które uruchomiło proces przygotowania do obrad Okrągłego Stołu. Dnia 15 września 1988 r. w Magdalence k. Warszawy doszło do kolejnego spotkania komunistycznych władz i „Solidarności”. Na to spotkanie został zaproszony ks. A. Orszulik, który odtąd będzie stałym obserwatorem ${ }^{27}$. Na uwagę zasługuje jeszcze jedno zdarzenie, mianowicie 16 października do Rzymu na uroczystości 10-lecia pontyfikatu Jana Pawła II udała się delegacja rządowa PRL-u na czele z Kazimierzem Barcikowskim, wiceprzewodniczącym Rady Państwa. Delegacja zajęła honorowe miejsce w auli Pawła VI, a nazajutrz Jan Paweł II spotkał się z K. Barcikowskim najpierw razem z delegacją, a następnie osobno ${ }^{28}$. Niedługo później ciosem w proces zbliżenia rządu i społeczeństwa stała się decyzja rządu Rakowskiego podjęta 31 października 1988 r. o likwidacji Stoczni Gdańskiej. Oznaczała zawieszenie rozmów. Na szczęście po kilku dniach na propozycję abp. Bronisława Dąbrowskiego, obydwie strony przystały na kolejne spotkanie między Lechem Wałęsą a Czesławem Kiszczakiem na gruncie kościelnym. Ta propozycja została przyjęta 11 listopada 1988 r. doprowadzając do przełamania impasu i przywrócenia nadziei ${ }^{29}$.

\section{1 listopada 1988 w katedrze na Wawelu w relacji Zdzisława Chłopka}

Ten kontekst dziejowy jest nieodzowny do zrozumienia tego co się wydarzyło 10 listopada 1988 r. w katedrze na Wawelu, w przededniu 70. rocznicy odzyskania niepodległości. W różnych wystąpieniach daje się odczuć zmiana w wydarzeniach dnia następnego, 11 listopada. Znajduje ona swój wyraz i w Kronice katedry na Wawelu i w relacjach z ogólnopolskich i krakowskich uroczystości umieszczonych w „Sowińcu” i w prasie codziennej ${ }^{30}$. Pośród nich jest relacja Zdzisława Chłopka z Nowego Sącza. Relację Z. Chłopka zamieszczam w całości nie tylko dlatego, że zawiera szczególnie dużo nowych informacji, ale dlatego, że dobrze oddaje klimat tych dni.

Autor kopię swojej pracy ofiarował ks. prałatowi Januszowi Bielańskiemu. Zatytułował ją „11 Listopada 1988 r. na Wawelu. Relacja własna (nieocenzurowana)". Jest to maszynopis, liczący 6 stron. Nie pierwsza odbitka, ale kolejna. $\mathrm{Na}$

27 J. Żaryn, Dzieje Kościoła katolickiego w Polsce (1944-1989), Warszawa 2003, s. 565-567.

28 Spotkanie papieża z Polakami w Rzymie, „Dziennik Polski” 44 (1988), nr 244 z dnia 18 X 1988, s. 1-2.

29 A. Dudek, R. Gryz, Komuniści i Kościół w Polsce..., dz. cyt., s. 426-435.

30 AKKK, b. sygn. Kronika katedry na Wawelu(1986-1997), k. 6-7; Chylimy głowę przed Wami wszystkimi..., „Dziennik Polski” 44 (1988), nr 263 z dnia 11 XI 1988 r., s. 1-2; Z uroczystości uczczenia 70. rocznicy odzyskania przez Polskę niepodległości, „Sowiniec” 8 (1989), s. 35; R. Hnatowicz, Przemówienie w Katedrze Wawelskiej, „Sowiniec” 8 (1989), s. 5860; A. Fischer, Sprawozdanie Komitetu Opieki nad Kopcem J. Pitsudskiego w roku 1988, „Sowiniec” 8 (1989), s. 61-63. 
odwrocie ostatniej szóstej strony dedykacja dla ks. J. Bielańskiego i adres autora relacji ${ }^{31}$.

\section{Edycja relacji}

„Powiadomiony wcześniej o uroczystościach pojawiłem się przed katedrą po godz. 16. Na dziedzińcu vis a vis bramy wejściowej grupka starszych panów (zapewne delegaci do pocztów sztandarowych); stoją i półgłosem wymieniają swoje uwagi.

Nieopodal kilku KPN-wców w wieku ok. 25-30 lat. W odróżnieniu od tamtych, żywo i nader głośno rozmawiają o sprawach związanych z uroczystościami. Jeden z nich wyjmuje z teczki cały plik zdjęć ze wspólnego marszu w dniu 6. Sierpnia b.r. na trasie Kraków-Kielce szlakiem 1 Kompanii Kadrowej. Przywołują jakąś znajomą dziewczynę. Jest blada i niespokojna. Inny młody człowiek otwiera torbę, w której jest magnetofon. Jeszcze inny niesie paliki do transparentów.

Po chwili u jednego z przybyłych pojawiają się w ręku słabo powielane najświeższe pisemka KPN-u. Znikają momentalnie, ludzie żądni wiadomości z drugiego obiegu rozchwytują je. Ktoś mruknął: Obserwują nas „S” („S” - to SB-ek). Inny dodał: On wie już o nas wszystko! Żołnierskim krokiem w mundurze z 39 roku (plutonowy) oraz hełmie nałożonym na głowę przechadza się sędziwy starzec z siwą brodą. Na chwilę przystaje przed wejściem do Katedry i żegna się trzykrotnie. Ktoś zauważył: To ten z prawosławia. Jakie 20 metrów dalej stoi młody, wysoki ksiądz i bacznie obserwuje całą sytuację.

Wodzę oczami za p. Jerzym. W jednej chwili przemknął w mundurze wśród stojących mężczyzn i zniknął w Katedrze. Podążyłem za nim do zakrystii, tam już tłoczno. Są delegaci do pocztów sztandarowych, harcerze i harcerki, młodzi adepci (w wieku 15-17 lat) ze szkółki ułańskiej w galowych mundurach i długich butach z cholewami z obsadzonymi na nich ostrogami. Wszyscy uśmiechnięci i przejęci ważnością chwili, która ma nadejść. Jest wśród nich także ich dowódca (ma może 19 lat), trochę nietypowy jak na ową uroczystość - długie włosy, pochylona postawa, niezdarny krok, nogi wciśnięte w cholewy - jak nie jego własne, ale cóż? Widocznie tak wypadło! Jest nadzieja, że w przyszłości tak on, jak też jego podkomendni przejdą odpowiednią musztrę, nabiorą poloru i przypomną tych sprzed 50 lat.

Tymczasem w zakrystii panuje niebywały pośpiech w uzupełnianiu garderoby, formowaniu pocztów. Przepycham się i wpadam wprost na p. Andrzeja. Panie Zdzisławie! Woła ku mnie - czekamy na pana. Niech pan szybko przygotowuje się do pocztu! Nic mi nie jest wiadomo - odparłem. Jak to, skoro Jerzy już mnie powiadomił. Szybko w kącie zakrystii ściągam z siebie podróżną koszulę, zakładam świeżą, na nią krawat i oto jestem gotów. Nie zapominam też o „bibułce”, którą przezornie wkładam do rękawiczki. Wszystkie klamoty pakuję do torby, którą

31 AKKK, b. sygn., Spuścizna ks. inf. J. Bielańskiego. Relacja Z. Chłopka, 11 listopada 1988 r. na Wawelu, Relacja własna [nieocenzurowana], k. 1-6. 
wsuwam głęboko pod ławkę. Pojawia się p. Jerzy, wręcza mi pospiesznie opaskę AK, przepasuje szarfą, wkładam furażerkę $\mathrm{z}$ orłem w koronie, białe rękawiczki i ustawiam się do pocztu. Na podaną komendę nad pocztami sztandarowymi - wygląda to trochę groteskowo!/ razem z innymi pocztami sztandarowymi schodzimy jako pierwsi do Krypty Marszałka Józefa Piłsudskiego wśród szpaleru tłumu z załzawionymi tu i ówdzie oczami. Raz po raz błyskają kamery. I oto Krypta. Ustawiamy się u rogu trumny, tuż przy głowie Marszałka. Przed nami warta honorowa harcerzy. Podciągają inne poczty. Obok nas są hutnicy z "Solidarności” Nowa Huta, w ładnych białych kombinezonach, przypominających krojem dawny strój Poleszuków, a naprzeciw z prawej strony trumny poczty 2 Korpusu Armii gen. Andersa.

Następuje zmiana warty harcerzy. W odróżnieniu od adeptów-ułanów, ci robią to zgrabnie i szykownie. Tu znać musztrę! Zewnętrznie prezentują się niemal okazale.

$\mathrm{Na}$ moment przed rozpoczęciem uroczystości wchodzi jeden z ostatnich żyjących i poruszających się o własnych siłach 90 letni legun w starannie zachowanej maciejówce na głowie, w asyście swej może 30-letniej prawnuczki. Wszyscy witamy go sympatycznymi spojrzeniami. Chwila rozrzewnienia. Na moment wydaje mi się, jak gdyby coś poruszało się w trumnie, jakby sam Marszałek chciał mu wyjść na spotkanie.

Boże! Gdyby to było w wolnej, niepodległej Polsce, zerwałyby się burzliwe owacje, a tu jak w katakumbach. Pan Ch. jest jedynym spośród tych kilku mieszkających w Krakowie, który zaszczyca tego rodzaju uroczystości, gdyż pozostali złożeni niemocą prawie nie wychodzą z domu.

Godzina 17. Rozpoczyna się uroczystość. Krótkie powitanie p. P. z „Solidarność - Małopolska", zapowiedź programowa, po czym następuje odśpiewanie hymnu narodowego. Po nim krótkie przemówienie p. P. z „Solidarności” nawiązujące do 70. rocznicy zmartwychwstania niepodległej Polski. Pan P. akcentuje: „Wczoraj odbyły się uroczystości rządowe, dziś naród składa hołd Wielkiemu Marszałkowi”. W przemówieniu są również ciepłe słowa dla stojącego wśród nas Leguna.

Następuje uroczystość składania wieńców przez kombatantów 2 wojny światowej, b. żołnierzy AK, „Solidarność”, KPN, Komitet Odbudowy Kopca J. Piłsudskiego, Górali z Zakopanego.

Duże poruszenie wywołuje złożenie wieńca przez konsula francuskiego z Krakowa od pana Prezydenta Rzeczypospolitej Polskiej w Londynie oraz od przedstawicieli ziemkostwa polskiego na obczyźnie. Tę podniosłą uroczystość kończymy odśpiewaniem I Brygady. W trakcie śpiewania nachodzą mnie różne refleksje:

Drogi Marszałku! Od dzieciństwa kochałem Cię gorącym sercem! Już wtedy, gdy jako 9-letni chłopiec /rok 1938/ deklamowałem ze wzruszeniem wiersze legionowe na uroczystościach szkolnych, jak też w dalszych kolejach życiowych, aż po dziś dzień. Idea sprawiła, że już po raz drugi stoję u Twych stóp w tak zaszczytnej asyście. Jest to największe przeżycie w całym moim życiu! 
Oddajemy salut i wychodzimy w pomieszanym ordynku na zewnątrz ku ołtarzowi. Znowu szpaler dumą przepojonych serc i kropliste łzy spływające po niektórych twarzach.

Ustawiamy się z lewej strony ołtarza jako pierwsi. Pan Jerzy jako komendant pocztu dba o to! Pan Andrzej dzierżący sztandar w swych żołnierskich dłoniach jest obok p. Jerzego drugą centralną osobą, na którą zwrócone są oczy wszystkich. Obaj okazale wyglądają w swych akowskich mundurach. Moja skromna osoba stojąca $\mathrm{z}$ lewej strony pocztu $\mathrm{w}$ cywilnym ubraniu tyle, że przybranym $\mathrm{w}$ poniektóre akcesoria nie wzbudza większego zainteresowania. Obok nas, jak w krypcie, hutnicy, za nimi Górale oraz delegacja kobiet w barwnych strojach regionalnych. Naprzeciwko kombatanci 2 Korpusu gen. Andersa w wojskowych mundurach i czarnych beretach, uczestnicy walk 39 roku, „Solidarność” - Małopolska, ludowcy AK, harcerze i adepci-ułani. W ławach z prawej strony ołtarza usadowili się w barwnych tradycyjnych strojach rajcy miejscy oraz członkowie Towarzystwa Bractwa Kurkowego.

Zbliża się godzina 18. I oto wspaniały chór z Krakowa pod batutą [wolne miejsce], otwiera po raz któryś z rzędu w artystycznym przemieszaniu dźwięków niezabliźnione rany kainowskiej zbrodni, która każdorazowo wstrząsa z tą samą mocą posadami sumień. Jest to „Chorał” Kornela Ujejskiego. Przy słowach: „Patrz! My w nieszczęściu zawsze jednacy" napęczniałych patriotycznym bólem tak wymownie przetransponowanym na dzisiejszą rzeczywistość i z taką gorącą ufnością skierowanym ku Bogu (tak tylko umie wyśpiewać Kraków). Wychodzi Msza św. z Krzyżem Chrystusowym na czele, niesionym przez młodego prezbiteriana. Celebruje ją sam Kardynał Jego Eminencja ks. Franciszek Macharski. Asystuje mu trzech dostojnych biskupów oraz trzech infułatów. Pozostali infułaci z dostojnego orszaku zajmują miejsca w ławach. Atłasowy reprezentacyjny fotel przeznaczony dla Głowy państwa pozostanie pusty...

Pochylają się sztandary. Chwila niezwykle uroczysta i podniosła. Przywodzi mi na myśl: gdyby ci wszyscy SBecy, ci ZOMO-wcy, którzy tam za murami Katedry i w innych miejscach Polski rozprawiają się brutalnie w tej oto chwili ze skandującym i manifestującym tłumem prawych Polaków, znaleźli się tu blisko, wyrwani z mroków narzuconej tyranii, ślepo i posłusznie spełniający rozkazy swoich zwierzchników, chyba by też poczuli żywsze drgnienia w swoich sercach i rozkruszyliby się w miłości, która jedna bratnie serca. Boć to przecież też Polacy, tyle, że zniewoleni. A czy ich zwierzchnicy też są aż tak zatwardziali, że nie chcieliby stanąć blisko Stołu Pańskiego, by przeżywać pospołu ze wszystkimi, z całym narodem wierzącym tę piękną uroczystość? Źle się dzieje w naszym narodzie, że zamiast zbliżenia pogłębia się przepaść! Tymczasem chór zaintonował nową pieśń.

Następuje homilia Jego Eminencji. Przesycona swą głęboką a jakże mądrą treścią przykuwa uwagę. Koduje się w mojej pamięci jeden z cytatów: Czy historia może płynąć pod prąd? Co za wspaniałe słowa! Po homilii rozbrzmiewa chór kolejnymi pieśniami. Moment Podniesienia i Komunia święta. 
Stoję niemal już dwie godziny w bezruchu i czuję nagle, że coś mi się słabo robi. Wiruje mi w głowie. Żeby tylko nie upaść, dopiero bym się zbłaźnił! Odruchowo kontroluję swoje kończyny, lekko poruszam korpusem, palcami u rąk i konstatuję, że wszystko jest w porządku! Zresztą, przyszło mi na myśl, oddać ducha w tak zaszczytnym miejscu niejeden by sobie zażyczył. Byle nie w ciężkich grzechach, a tych na szczęście nie mam.

Z tych wewnętrznych wynurzeń podnoszę nagle wzrok i skierowuję na siedzącego na wprost mnie przemiłego staruszka proboszcza o niezwykle dobrotliwej i przemiłej twarzy. Utkwił on we mnie wzrok, jak gdyby chciał nim przeniknać, ile ojczyźnianego serca mieści się pod tą zewnętrzną powłoką niepozornego członka pocztu sztandarowego. Oj bardzo dużo, kochany księże! - odpowiedziałem w niemym spojrzeniu zacnemu kapłanowi.

Msza dobiega końca. Śpiewamy na przemian z chórem: „Ciebie Boże wysławiamy”, oraz wspólnym mocnym głosem „Boże coś Polskę” z niezmieniającym się już wersetem: „Ojczyznę wolna racz nam zwrócić Panie”. Końcowe błogosławieństwo Kardynała. Pochylenie sztandarów, po czym dostojni Biskupi i Proboszczowie z Jego Eminencją odchodzą od ołtarza. Na ornacie Ks. Kardynała połyskują w blasku świateł trzy zdobione haftem napisy: Bóg, Ojczyzna, Honor.

Pogrążony w głębokiej zadumie przenikniętej bezbrzeżną troską o losy Ojczyzny i Kościoła, dostojny orszak włodarzy polskich serc i sumień opuszcza pod przewodem Krzyża Chrystusowego Święte Prezbiterium.

Niestrudzony, zawsze życzliwy, zawsze serdeczny i oddany sprawie proboszcz katedry ks. prałat Bielański pilnie dogląda, czy wszystko jest w porządku, a potem jako ten Dobry pasterz schodzi ze swymi owcami przybranymi w poczty sztandarowe ponownie do Krypty Marszałka.

Przepełniony thum znowu odprowadza nas przyjaznymi spojrzeniami. Tam wszyscy składamy hołd pożegnalny ukochanemu Marszałkowi odśpiewaniem 1 Brygady, po czym szykujemy się ku wyjściu do zakrystii.

Tymczasem do uszu naszych dobiegają od zewnątrz skandowane okrzyki. Trudno je zrozumieć, ale zbity tłum wrze i huczy! To daje znać o sobie Polska! Patriotyczna młodzież i dorośli!

Atmosfera na zewnątrz nie nastraja optymistycznie. Czyżby nowe ofiary? Wieszcze słowa „Testamentu” J. Słowackiego zda się, odżywają na nowo: „A potem niechaj wszyscy idą po kolei - jak kamienie przez Boga rzucone na szaniec”.

W zakrystii każdy szybko „ucywila” się. Ks. Bielański jak gdyby w przeczuciu czegoś niedobrego rozpoczyna $\mathrm{z}$ nami odmawianie różańca. Po nim następuje krótka modlitwa, po czym całą trójką z naszego pocztu próbujemy wydostać się na zewnątrz. Pan Andrzej, który zna wszystkie zakamarki Zamku, wsparty laską, tajemnymi tylko sobie przejściami przeprowadza p. Jerzego i mnie przez jakoweś krużganki wprost na boczne wyjście. Z przeciwnej strony dochodzi nas przez megafon głos funkcjonariusza MO: „Ponawiamy rozkaz natychmiastowego rozejścia się”. Jakby w odpowiedzi thum huczy dalej i skanduje okrzyki. 
Jesteśmy już całą trójką na ulicy, wmieszani w tłum. Tym razem obeszło się bez starć z milicją. Zrelacjonował mgr Zdzisław Chłopek. Kraków, 11.11.1988 r.”

Narodowe Święto Niepodległości zostało przywrócone trzy miesiące później ustawą z 15 lutego 1989 r. $^{32}$ Odtąd katedra na Wawelu jest miejscem, na którym w sposób nieskrępowany każdego roku obchodzony jest 11 listopada jako Święto Niepodległości.

\section{BIBLIOGRAFIA}

\section{Źródla archiwalne:}

\section{Archiwum Kapituly Katedralnej w Krakowie:}

b. sygn., Spuścizna ks. inf. J. Bielańskiego, Relacja Zdzisława Chłopka z uroczystości 11 XI $1988 \mathrm{r}$.

b. sygn., Spuścizna M. Boruty-Spiechowicza, Przemówienie gen. Boruty-Spiechowicza z 11 XI $1977 \mathrm{r}$.

b. sygn., Kronika katedry na Wawelu (1986-1997).

\section{Instytut pamięci Narodowej Oddział w Krakowie:}

sygn. IPN Kr 010/9303/4, Meldunki operacyjne z 11 XI 1980.

\section{Źródła drukowane:}

Barcikowski K., U szczytów władzy, Warszawa 1998.

Dokumenty uczestników Ruchu Obrony Praw Człowieka i Obywatela 1977-1981, Kraków 2005.

„Dziennik Ustaw” 1989, nr 6, poz. 34.

Kalendarium roku Marszałka J. Pitsudskiego w Krakowie, opr. J. Giza, B. Kuras, W. Steckiewicz, Kraków 1985.

Figlewicz K., Kronika katedry na Wawelu 1934-1982, opr. J. Urban, E. Zych, Kraków 2014.

Komunikaty Konferencji Episkopatu Polski 1945-2000, opr. J. Żaryn, Warszawa 2006. Nauczyciel i Pasterz. Ks. kard. Karol Wojtyła, Listy pasterskie - Komunikaty - Zarządzenia 1959-1978, opr. M. Jagosz, Rzym 1987.

Opozycja Małopolska w dokumentach 1976-1980, Kraków 2003.

Przemówienie J.E. kard. Karola Wojtyly na opłatku legionowym w Krakowie w dniu 25 stycznia 1975 r., „Sowiniec” 6 (1986), s. 41.

32 „Dziennik Ustaw” 1989, nr 6, poz. 34. 


\section{Opracowania:}

Encyklopedia Solidarności. Opozycja w PRL 1976-1989, t. 1, Warszawa 2010.

Chylimy głowe przed Wami wszystkimi..., „Dziennik Polski” 44 (1988), nr 263 z dnia 11 XI 1988 r., s. 1-2.

Dudek A., Gryz R., Komuniści i Kościót w Polsce (1945-1989), Kraków 2003.

Fischer A., Sprawozdanie Komitetu Opieki nad Kopcem J. Pitsudskiego z działalności w roku 1988, „Sowiniec” 8 (1989), s. 61-63.

Fischer I., Obchody Święta Niepodległości w międzywojennym Krakowie, „Sowiniec" 15 (1999), s. 42-47.

Hnatowicz R., Przemówienie w Katedrze Wawelskiej, „Sowiniec” 8 (1989), s. 58-60.

Jagosz M., Katedra wawelska za czasów pasterzowania arcybiskupa Karola Wojtyły, w: Karol Wojtyła jako biskup krakowski, red. T. Pieronek, R. Zawadzki, Kraków 1988, s. 135-155.

Kajzar P., Mauzoleum marszałka Józefa Pitsudskiego na Wawelu w latach 19351989, Kraków 2018.

Lewandowski M., Pawlikowski M., Gaz na ulicach, Kraków 2011.

Nowak J., Pamięci Pana Kazimierza Martyniaka, „Sowiniec” 5 (1985), s. 33.

Spotkanie papieża z Polakami w Rzymie, „Dziennik Polski” 44 (1988), nr 244 z dnia 18 X 1988 r., s. 1-2.

Urban J., Katedra na Wawelu w relacji ks. K. Figlewicza w latach 1939-1945, „Analecta Cracoviensia" 28 (1996), s. 569-580.

Urban J., Katedra na Wawelu po 1918 r., Kraków 2008.

Z uroczystości uczczenia 70. rocznicy odzyskania przez Polskę niepodległości, „Sowiniec" 8 (1989), s. 35.

Żaryn J., Dzieje Kościoła katolickiego w Polsce (1944-1989), Warszawa 2003.

\section{Streszczenie}

Ustawą z 23 kwietnia 1937 r. dzień 11 listopada stał się w Polsce Świętem Niepodległości. Ustawa związała ten dzień z osobą Józefa Piłsudskiego. Autor podjął temat form świętowania 11 listopada w katedrze na Wawelu jako miejscu spoczynku trumny J. Piłsudskiego. Najpierw pokrótce omówił świętowanie 11 listopada w latach bezpośrednio poprzedzających wybuch II wojny światowej. Następnie omówił formy pielęgnowania 11 listopada przez legionistów i środowiska niepodległościowe po zaprowadzeniu przez władze komunistyczne nowego święta 22 lipca i ignorowaniu święta 11 listopada. W ostatniej części Autor edytuje relację z przebiegu uroczystości 11 listopada 1988 r., która była zapowiedzią zmian politycznych w Polsce, które trzy miesiące później doprowadziły 
do ustawy z 15 lutego 1989 r. o przywróceniu 11 listopada jako Narodowego Dnia Niepodległości.

Słowa klucze: Józef Piłsudski, Zdzisław Chłopek, Związek Legionistów Polskich, Święto Niepodległości, katedra na Wawelu, Kraków

Zdzistaw Chtopek's Account of the Religious and Patriotic Celebrations of the 70th Anniversary of Polish Independence at Wawel Cathedral (11 November 1988)

\section{Summary}

The Act of April 23, 1937 established November 11th as Poland's Independence Day. That same act bound that day with the person of Józef Piłsudski. The author depicts the form and type of the November 11th celebration in Wawel Cathedral, which is the resting place of J. Piłsudski. First, he briefly discusses the November 11th celebration in the years immediately preceding the outbreak of World War II, then discusses the forms of celebration by legionnaires and independent circles after communist authorities introduced an official ban on celebration. In the final part of the article, the author the author recounts the ceremony of November 11, 1988, which was a preview of political changes in Poland, and three months later led to the Act of February 15, 1989 which restored November 11 as National Independence Day in Poland.

Key words: Józef Piłsudski, Zdzisław Chłopek, Polish Legionnaires' Union, Independence Day, Wawel cathedral, Krakow 